\title{
The Effect of Learning with Reversible Problem-Solving Approach on Prospective-Math-Teacher Students' Reversible Thinking
}

\section{Syarifatul Maf'ulah}

STKIP PGRI Jombang, East Java, Indonesia, syarifatul.m@gmail.com

\section{Dwi Juniati}

Universitas Negeri Surabaya, Surabaya, East Java, Indonesia, dwi_juniati@yahoo.com

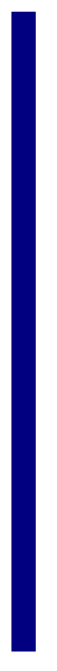

This study aimed to determine the effect of learning with reversible problemsolving approach on prospective-math-teacher students' reversible thinking. Using experimental research design, the study involved 65 prospective math teacher students as respondents (35 experimental, 30 control). Experimental class implemented a learning with reversible problem-solving approach as the treatment; thing the control class would not do so. A post-test on reversible thinking was applied to both classes for data collection of the students' reversible thinking, and it was further analyzed using t-test via SPSS 23 . The result found that the mean score of experimental class was 76.7143, while the control class was 35.3333. A significant difference between their mean score was evident. Hence, it indicated that the post-test of experimental class was considered better than the control one. This post-test result was further analyzed using equal variance assumed t-test via SPSS 23. Result showed that there was a significant difference between both classes on their post-test score. Thus, the study established that learning with reversible problem-solving approach definitely brought effect on prospectivemath-teacher students' reversible thinking ability. The effect was significant and positive.

Keywords: reversible problems approach, reversible thinking, learning, problemsolving, teacher, student

\section{INTRODUCTION}

The researchers always felt interested in investigating the theory development of reversible thinking in education field, particularly those dealing with mathematics learning. It was due to few references (both published articles and literature) on either students' or teachers' reversible thinking. It was based on their searching on many literatures and journals, both national and international ranges. It was supported by Lamon (2007) that few literatures and studies about reversibility. Therefore, Lamon 
called out many researchers, especially in education field, to take concern on, to study, and to review students' reversibility since it was fundamental for them in education field, especially in math learning (Maf'ulah, et. al., 2016, Maf'ulah, et. al., 2017, Maf'ulah, et. al., 2019, Fanders 2014, Lamon 2007, Ramful \& Olive 2008, Krutetskii 1976). Only few studies of reversible thinking were found might be due to teachers' less concern on the importance of reversible thinking for both students and teachers.

One reason why teachers should take their concern on their students' reversible thinking in math learning is the fact that it is a part of mathematics competence which may affect their success on problem-solving (Krutetskii, 1976). Problem-solving is the heart of math learning as it is an inseparable part of any math learning (Soedjadi, 1992; NCTM, 2000). Mathematics learning may never be meaningful without problem-solving.

As its importance on math learning, the supporting aspects for students' success on problem-solving should be taken into account. One of those aspects refers to their reversible thinking. Hence, teachers need to develop and optimize students' reversible thinking to make them capable of solving problems. Before developing students' reversible thinking, however, teachers self should have this competence at first. Therefore, the subject of this study was prospective-math-teacher students as they might take it as stock for their future career as teachers.

Piaget argued that reversible thinking was an individual's mental capability to reverse his/her thinking back to where it had been started (Slavin, 2006). Thinking reversible is a mental activity that gets an individual to think logically in two reversible ways, making a two-way connection among concepts, principles, and procedures to strengthen the scheme (Flanders, 2014). Maf'ulah et al. (2019) argued that in using reversible thinking, students are required to think twice in opposite viewpoints in order to minimize any possible errors in every decision they made.

In a theory that Piaget developed (Inhelder\&Piaget, 1958), the concept of reversible thinking was classified into two types; negation and reciprocity. Negation involved an understanding that one-way move might be forgone by the reversal move. Whereas, reciprocity dealt with compensations or equivalent relationships. Following Adi (1978), Ramful (2009), and Hackenberg (2010), it had two kinds of ways to do reversible thinking; inversion and reciprocity. Using inversion, it dealt with inversion (in case that the problem was related to algebra). On the other hand, thinking reversible through reciprocity dealt with a reciprocal or equal relationship; one was not only capable to achieve the expected goals, but also turned back to where he/she had started.

Maf'ulah, et. al. (2017) argued that three aspects of reversible thinking were identified including: (1) negation, in case that the subject used inverse on the pertinent operation; (2) reciprocity, in case that the subject used compensation or any other equivalent relationships; (3) a competence to turn back to the initial path after achieving the goal.

Based on some published articles and journals of reversible thinking the researchers had searched, most of them suggested algebra to identify students' reversible thinking. 
Adi (1978), majoring in education field, was one of the examples. He used both negation and compensation to complete an equation: $14-\frac{15}{7-x}=9$ To define the value of $\mathrm{x}$, he might involve either negation or reciprocity. In cased that he involved negation as the approach, the question might be "How many it should subtract 14 to result into 9?", "How many it should divide 15 to result into 5?", "How many it should subtract 7 to result into 3 ?" In case that he involved reciprocity, he might multiply both

sides of equation by $7-x$, and thus it resulted into $98-14 x-15=63-9 x$. Ramful (2009) argued that reversible thinking in math was related to arithmetic, fraction, ratio, algebra, and some other cases. Involving arithmetic, for example, the problem might be: "Jim has 5 marbles. His marbles is eight (8) less than Connie. How many marbles the Connie has?" Wong suggested that reversibility was fundamental to the concept of addition. Copeland (in Wong, 1977) illustrated the condition of reversibility in the

concept of addition as follow: "In case that a kid sees that $3+2=5$, he must be able to answer and complete this problem: $5=\cdots+2$ or $3+\cdots=5$ ?" In case that he could answer the problem, his reversible thinking has developed since he got that $3+2=5$ was equal to $5=3+2$ ".

Maf'ulah, et al (2017) suggested two fundamental aspects in reversible thinking; forward and reverse. Forward referred to a mental process from the initial state to the expected goal, while reverse referred to a mental process from the achieved goal back to the initial state. If reverse was considered as a process of turning back to the initial state of thing, it seemed that reverse involved either inversion or negation. Dreyfus \& Eisenberg (1996) defined reversible thinking as a reversal of thinking; a process of thinking from the result to the resource that made the result. Furthermore, Krutetskii (1976) argued that it was an individual's mental process to go back to the initial state in which he started after achieving the result. Hence, on which an individual reverse the final result of thing into its initial state, he has implemented reversible thinking on his way. Relating to the stages of problem solving, Polya (1972) saw looking back as the aspect of reversible thinking by which the student substituted the answer/final result to the problem/data that made the result.

Overall, three characteristics of reversible thinking were found including inversion, reciprocity, and looking-back. Hence, to drill students' reversible thinking, teachers might do some strategies, such as (1) providing reversible problems and (2) asking the students to do looking-back in each of the problem solving. Looking back was applied by substituting the final answer to the problem/source creating the result. Therefore, this study focused on providing some reversible problems to be solved by students.

Reversible problems were opposite problems or reverse problems. Two problems were said to be opposite if (1) the first problem were related to inverse, while the second problem was not related to inverse but both problems were in the same context, or (2) when viewed in terms of known and asked on problem. For example, what is known in 
the first problem is A and what is asked is B, then what is known in the second problem is B and what is asked is A. As stated by Ramful (2015), Ramful uses the terms primal problem and dual problem. According to Ramful, “......in the primal problem the source and relation are specified and the aim is to find the result. While in the dual problem the result and relation are specified and the aim is to find the source". In this case, solving reversible problems was applied as the learning approach in this study. Solving problems is one's attempt to overcome a non-routine problem by utilizing all insight and competence he already has (Shumway 1980; Polya, 1973; Branca, 1980:7).

Reversible thinking could be developed in mathematics learning by stressing on giving reversible problems. Learning is the interaction between teacher and student and learning resources in a learning environment (UU No.20, 2003). Learning with With reversible problem-solving approach is a mathematics learning that emphasizes the solving of reversible problems. Activities the lecturers needed to do implementing this learning involved (1) explaining the learning objectives; (2) explaining the learning material; (3) forming several groups; (4) providing student worksheets, worksheets contain reversible problems that must be solved by students; (5) asking students to work on the worksheet; (6) guiding the process of solving reversible problems; (7) asking several groups to present the results of the work in the form of a process of solving reversible problems for joint discussion; (8) giving conclusion about learning material. The learning material was complex function and transformation.

With this approach in learning, two benefits were expected to happen; (1) it might drill students' reversible thinking, and (2) it might automatically sharpen students' capability in problem solving which became the core of math learning.

\section{Learning Material}

The learning material was complex function. Thus, the researchers would like to describe this material. Learning with reversible problem-solving approach was did for three meeting.

Learning material for first meeting was complex function and inverse of complex function. Definition of complex function of set A to set B is a relation that pairs each element in set A to elements in set B. In this case, A is the domain and B was the result. Both set $\mathrm{A}$ and $\mathrm{B}$ are the subset of a set of complex number. There are two kinds of complex function; single-valued and multiple-value. If only one value of w corresponds to each value of $\mathrm{z}$, we say that $\mathrm{w}$ is a single-valued function of $\mathrm{z}$ or that $\mathrm{f}(\mathrm{z})$ is singlevalued. If more than one value of $w$ corresponds to each value of $z$, we say that $w$ is a multiple-valued or many-valued function of z (Spiegel, et. al, 2009).

Definition of inverse of complex function was "if $w=f(z)$, then we could also consider $\mathrm{z}$ as a function, possibly multiple-valued, of $\mathrm{w}$, written $\mathrm{z}=\mathrm{g}(\mathrm{w})=\mathrm{f}^{-1}(\mathrm{w})$ ". The function $\mathrm{f}^{-1}$ is often called the inverse function corresponding to $\mathrm{f}$. Thus, $\mathrm{w}=\mathrm{f}(\mathrm{z})$ and $\mathrm{z}=\mathrm{f}^{-1}(\mathrm{z})$ are inverse functions of each other (Spiegel, et. al, 2009).

Worksheet was given by lecture for first meeting was reversible problems as follow.

Problem 1: Given some example of the single-valued and multiple-valued complex function! 
Problem 2: If given some complex function as follow

$\mathrm{f}(\mathrm{z})=\mathrm{z}^{1 / 2}$

$\mathrm{f}(\mathrm{z})=\mathrm{z}+\mathrm{i}$

$f(z)=(z+i)^{-1}$

$f(z)=\left(z^{2}\right)^{1 / 2}$

which one is the single-valued and multiple-valued complex function!

Problem 3: If $f(z)=2 z$ - i then find the inverse of $f(z)$ !

Problem 4: If $\mathrm{f}^{-1}(\mathrm{z})=1 / 2(\mathrm{z}+\mathrm{i})$ then find $\mathrm{f}(\mathrm{z})$ !

Learning material for second meeting was transformation. Definition of transformation was "if $\mathrm{w}=\mathrm{u}+\mathrm{iv}$ (where $\mathrm{u}$ and $\mathrm{v}$ are real) is a single-valued function of $\mathrm{z}=\mathrm{x}+$ iy (where $\mathrm{x}$ and $\mathrm{y}$ are real), we can write $\mathrm{u}+\mathrm{iv}=\mathrm{f}(\mathrm{x}+\mathrm{iy})$. By equating real and imaginary parts, this is seen to be equivalent to $u=u(x, y), v=v(x, y)$. The set of equations $u=$ $\mathrm{u}(\mathrm{x}, \mathrm{y}), \mathrm{v}=\mathrm{v}(\mathrm{x}, \mathrm{y})$ [or the equivalent, $\mathrm{w}=\mathrm{f}(\mathrm{z})$ ] is called a transformation.

Worksheet was given by lecture for second meeting was reversible problems as follow.

Problem 1: If $f(z)=i z^{2}-2$, find the result of transformation of $z_{1}=2-i$ and $z_{2}=1+3 i$ through a complex function $\mathrm{f}(\mathrm{z})$ !

Problem 2: If $f(z)=i z^{2}-2$ and the result of transformation from $z$ through $f(z)$ is $2-3 i$, find $\mathrm{z}$ !

Problem 3: If $\mathrm{f}(\mathrm{z})=2 \mathrm{zi}-\mathrm{z}^{2}$ then find the transformation!

Problem 4: If the transformation of $z$ through $f(z)$ is $y^{2}-x^{2}-2 y+2 x(1-y) i$, find $f(z)$ !

Learning material for third meeting was representation complex function and the transformation geometrically. To represents a complex function geometrically, it needs two planes; z plane and w plane. z plane represents the domain, while w plane represents the result of transformation from each point of domain through a function $\mathrm{f}(\mathrm{z})$.

For instance, a complex function $f(z)$ is given. The domain of $f(z)$ is a graphic with the first point at $\mathrm{z}_{1}$ and the last point at $\mathrm{z}_{2}$ as presented in $\mathrm{z}$ plane. The result of transformation from this domain is a graphic with the first point at $f\left(z_{a}\right)$ and the final point at $\mathrm{f}\left(\mathrm{z}_{\mathrm{b}}\right)$, as presented in $\mathrm{w}$ plane. The following figure presented a geometrically complex function

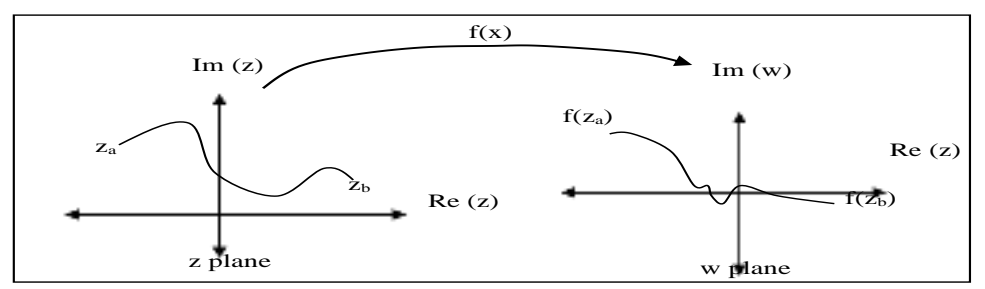

Figure 1

The Representation of a Complex Function and the Transformation Geometrically 
Worksheet was given by lecture for third meeting was reversible problems as follow.

Problem 1: If $\mathrm{f}(\mathrm{z})=\mathrm{z}^{2}$ then represent geometrically the result of transformation of $\mathrm{z}_{1}=-$ $1-2 \mathrm{i}$ and $\mathrm{z}_{2}=3+2 \mathrm{i}$ !

Problem 2 : Given an function $f(z)=z^{2}$, if the result of transformation of $z$ through $f(z)$ was given by graphic as follow, then find $\mathrm{z}$ !

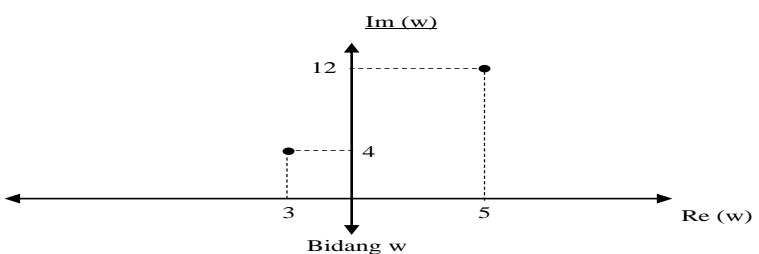

\section{METHOD}

\section{Experimental Design}

It was a quantitative experimental method since this study aimed to ensure the effect of treatment of learning with reversible problem-solving approach on prospective-mathteacher students' reversible thinking. According Sugiyono (2012), the method of experimental research was a method to figure out the effect of particular treatment on the studied objects in a controlled condition. And the quantitative method was used to investigate particular population or sample, using particular instrument for data collection, and having quantitative/statistic data analysis in order to test the hypotheses (Sugiyono, 2012). The study had complied with the ethical standards, because author had asked free, prior and informed consent.

\section{Research Design}

The design of this research is posttest-only control group design. The following figure presented the research design of this study.

\begin{tabular}{|c|c|c|}
\hline E : & $X$ & $\mathrm{O}_{1}$ \\
\hline $\mathrm{C}$ & & $\mathrm{O}_{2}$ \\
\hline
\end{tabular}

Figure 2

Experimental Design (Sugiyono, 2015)

The description of figure 2 is as follow.

$\mathrm{E}$ is the experimental group, while $\mathrm{C}$ is the control group, and $\mathrm{X}$ is the treatment to the experimental group. The treatment is in the form of a learning implementation by solving reversible problems. $\mathrm{O}_{1}$ is the post-test result of students in experimental group, particularly to their reversible thinking after having such treatment. $\mathrm{O}_{2}$ is the the posttest result of students in control group; those with no treatment. The treatment was considered having significant effect on students' competence if it found a significant difference on the result of post-test between experimental and control groups.

The experimental group would have particular treatment (e.g., for instance, group X), while the control group did not have such treatment as group X had (Kothari, 2004). 
When the control class was not given the same treatment as the experimental class, it did not mean that the control class had no treatment or teaching. The control group would have an instruction but it was not reversible problem-solving approach.

\section{Hypotheses}

Hypothesis is a temporary based on particularly theoretical review. The hypotheses of this study are as follow.

$\mathrm{H}_{0}$ : No difference is found on post-test score between experimental and control groups

$\mathrm{H}_{1}$ : There is a difference on post-test score between experimental and control groups

\section{Participant}

The sample of this study was 65 prospective-math-teacher students at a tertiary institution in East Java, Indonesia with the population was 102 prospective-math-teacher students. They were divided into control group (30 students) and experimental group (35 students). The control class consisted of 8 males and 22 females, while the experimental class consisted of 9 males and 26 females. All students are around 19 years old. The sample was chosen using random techniques as Sugiyono (2015) suggested, it randomly selected two groups; experimental and control groups, i.e the sample class was chosen randomly with the consideration that all classes had a homogeneous average of mathematical abilities. This was based on the preliminary test result data given to all classes. So the control class and the experimental class had equivalent initial abilities.

\section{Instrument}

This instrument was a test. Before the test was given to students, it was first validated by using product moment correlation test $r_{x y}$ through SPSS 23. The number of questions was considered valid if the value of $r_{x y}$ was at least 0.40 . for reliability, it used Cronbach's Alpha $r_{11}$ through SPSS 23. The instrument was considered reliable if $r_{11}>$ 0.60 (Arifin, 2010). So the test instrument was validated and item-analyzed before it was given to the experimental and control groups.

\section{Procedures}

Learning with With reversible problem-solving approach was implemented in experimental group for three meetings and posttest was given at the fourth meeting. It took $2 \times 50$ minutes for each meeting. In control group, the students got the same material as the experimental group had. However, they did not apply reversible problem-solving as the treatment. Furthermore, both groups had the same validated post-test.

\section{Technique of Data Analysis}

The data of this study was in the form of students' post-test scores to be analyzed using a statistic calculation. To see the treatment (i.e., the effect of learning with reversible problem solving) on its significance, a difference-test analysis using t-test was conducted. The treatment was considered having significant effect if it found a significant difference between experimental and control groups on their post-test score. Before analyzing the data through t-test, a test of normality and homogeneity should be conducted at first. The test of normality aimed to see whether or not the data distribution 
was normal, and the test of homogeneity aimed to test the similarity between both groups; experimental and control groups.

\section{FINDINGS}

\section{Instrument Development}

The instrument of this study was a post-test for both experimental and control groups in final meeting. The test was designed by referring to the students' reversible thinking. Reversible thinking test can contain conflicting problems. for example, problems on following figure.

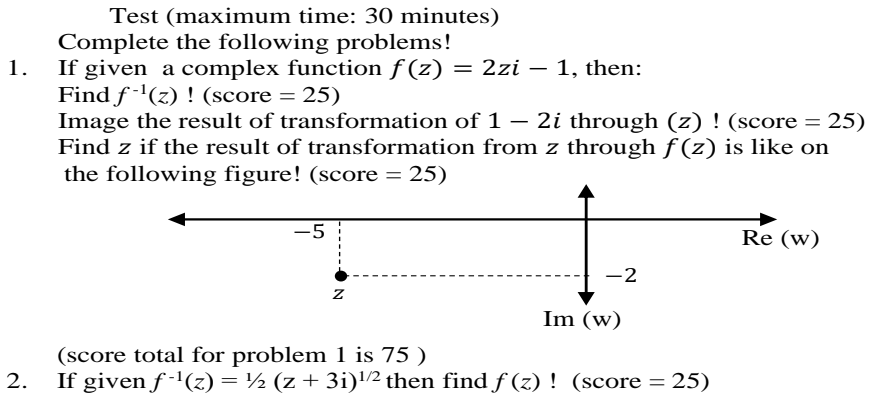

(score total for problem 1 is 75 )

2. If given $f^{-1}(z)=1 / 2(z+3 i)^{1 / 2}$ then find $f(z) !($ score $=25)$

Figure 3

Test Instrument of Study

Before giving the post-test to both groups, it should be shared at first to particular class for validation and reliability purposes. The experimental class was selected as the place to test the validity and reliability of the post-test. The test score was then analyzed on its validitiy by using product moment correlation test $r_{x y}$ through SPSS 23 . The number of question was considered valid if the value of $r_{x y}$ was at least 0.40 . for reliability, it used Cronbach's Alpha $r_{11}$ through SPSS 23. The instrument was considered reliable if $r_{11}>$ 0.60 . The result of validation test through SPSS 23 was presented in the following table.

Table 1

The Result of Instrument Validation Test

\begin{tabular}{lll}
\hline & Correlations & Sig. (2-tailed) \\
\hline Problem 1 & .924 & .000 \\
Problem 2 & .947 & .000 \\
\hline
\end{tabular}

Table 1 showed that the correlation of both problem 1 and 2 respectively were 0.924 and 0.947. It indicated that both problems were valid, as they were greater than 0.40 . Furthermore, it found that the value of Cronbach's Alpha $r_{11}$ was 0.852, indicating that the instrument was reliable.

\section{Test of Normality}

The test of normality aimed to ensure whether or not the data distribution was normal. The following table presented the result of normality test on post-test data by using chisquare on SPSS 23. 
Table 2

Result of Normality Test on Post-Test Data

\begin{tabular}{lll}
\hline & posttest_experiment & posttest_control \\
\hline Chi-Square & $7.200^{\mathrm{a}}$ & $11.067^{\mathrm{b}}$ \\
\hline Df & 6 & 7 \\
\hline Asymp. Sig. & .303 & .136 \\
\hline
\end{tabular}

The Output of SPSS 23 showed that the value of Asymp. Sig for experimental class on their post-test data was $.303>0.05$, while the control class was .136>0.05. Rozak and Hidayati (2013) argued that the data distribution is considered normal if the valued of

Asymp. Sig. was $>0.05$ with significant rate at $5 \%(\propto c=0.05)$. It indicated that the data distribution of post-test in both experimental and control groups were normal.

\section{Test of Homogeneity}

This test aimed to compare two groups of data (i.e., experimental and control groups), whether or not they had similarity in variance. Both of the groups could be compared only if they had the same variance. If the data was homogeneous, equal variances assumed t-test could be conducted. Otherwise, equal variances not assumed t-test was applied when the data was not homogeneous. The data was considered homogeneous if

the Sig. value $>0.05$ with the rate of significance at $5 \%\left(\alpha^{2}=0.05\right)$. the following table presented the result of homogeneity test using SPSS 23.

Table 3

Result of Homogeneity Test

\begin{tabular}{lllll}
\hline & Levene Statistic & df1 & df2 & Sig. \\
\hline Chi-Square & .349 & 1 & 63 & .557 \\
\hline
\end{tabular}

The result of homogeneity test as presented in Table 4 showed that the Sig. value was $.557>0.05$, indicating a normal distribution on the data of both experimental and control groups.

The Effect of Learning with Reversible-Problem-Solving Approach on Prospective-Teacher Students' Reversible Thinking

The hypotheses of this study were as follow.

$\mathrm{H}_{0}$ : No difference is found on post-test score between experimental and control groups

$\mathrm{H}_{1}$ : There is a difference on post-test score between experimental and control groups

To see the treatment based on its significance, we needed to do a test analysis of

difference using t-test in SPSS 23 with significant rate at 5\% 5\% $(\propto=0.05)$. The criteria

of not supporting $\mathrm{H}_{0}$ was " $\mathrm{H}_{0}$ is not supported if the Sig. value $<\propto$ ", indicating a difference between experimental and control groups on their post-test scores.

If a significant difference was found between those two groups, it indicated that the treatment gave significant effect on the experimental group. In this case, the treatment 
referred to implementing a reversible-problem-solving approach in a learning process. As the data of both groups was homogeneous, it used equal variances assumed t-test. The following table showed the result of equal variances assumed t-test through SPSS 23 to test the hypotheses of this study.

Table 4

Result of Equal Variances Assumed t-Test

\begin{tabular}{|c|c|c|c|c|}
\hline & & & \multicolumn{2}{|l|}{ Score } \\
\hline & & & $\begin{array}{l}\text { Equal variances } \\
\text { assumed }\end{array}$ & $\begin{array}{l}\text { Equal variances } \\
\text { not assumed }\end{array}$ \\
\hline \multirow{2}{*}{$\begin{array}{l}\text { Levene's Test for } \\
\text { Equality of Variances }\end{array}$} & \multicolumn{2}{|l|}{$\mathrm{F}$} & .349 & \\
\hline & \multicolumn{2}{|l|}{ Sig. } & .557 & \\
\hline \multirow{7}{*}{$\begin{array}{l}\text { t-test for Equality of } \\
\text { Means }\end{array}$} & \multicolumn{2}{|l|}{$\mathrm{T}$} & 8.260 & 8.367 \\
\hline & \multicolumn{2}{|l|}{ Df } & 63 & 62.994 \\
\hline & \multicolumn{2}{|l|}{ Sig. (2-tailed) } & .000 & .000 \\
\hline & \multicolumn{2}{|l|}{ Mean difference } & 41.38095 & 41.38095 \\
\hline & \multicolumn{2}{|l|}{ Std. Error difference } & 5.00996 & 4.94596 \\
\hline & \multirow{2}{*}{$\begin{array}{l}95 \% \text { Confidence Interval } \\
\text { of the Difference }\end{array}$} & Lower & 31.36934 & 31.49722 \\
\hline & & Upper & 51.39257 & 51.26468 \\
\hline
\end{tabular}

Based on Table 4, the Sig. value (2-tailed) was .000 $<0.05$. Thus, $\mathrm{H}_{0}$ was not supported, while $\mathrm{H}_{1}$ was supported since a difference on post-test score between experimental and control groups was found. Thus, implementing learning with reversible-problem-solving approach affected the reversible thinking of prospective-math-teacher students. The mean score of post-test between those two groups, as presented in following table, supported this finding.

Table 5

Mean Score of Post-Test

\begin{tabular}{llllll}
\hline & Group & $\mathrm{N}$ & Mean & Std. Deviation & Std. Error Mean \\
\hline \multirow{2}{*}{ Post test score } & experiment group & 35 & 76.7143 & 21.58917 & 3.64924 \\
\cline { 2 - 6 } & control group & 30 & 35.3333 & 18.28573 & 3.33850 \\
\hline
\end{tabular}

Mean score of post-test in experimental group was 76.7143, while the control group was 35.3333. It was clear that the mean score of experimental groups is significantly higher than the control group, and thus, it showed a significant difference between them on their scores.

\section{DISCUSSION}

The results showed that there was a significant difference between the posttest score in the experimental class and the posttest score in the control class. Students in the experimental class had a higher posttest score than students in the control class. The experimental class was a class that was given treatment in the form of the implementation of learning with an the reversible-problems-solving approach. This means that the reversible-problems-solving approach could be used to train the reversible thinking skills of prospective mathematics teacher students, and it was main finding of this study. Reversible-problems-solving in this study were in line with Ramful's thinking (Ramful, 2015), but Ramful used the terms primal problem and dual 
problem. Acccording Ramful, in the primal problem the source and relation are specified and the aim is to find the result. While in the dual problem the result and relation are specified and the aim is to find the source. So, the primal problem and the dual problem that refers to Ramful were two reversible problems each other.

Based on the search of researchers in previous studies, researchers had not found a learning approach that was used to improve or practice the ability of reversible thinking. Previous studies focused on analyzing students 'reversible thinking, not on learning strategies that could train students' reversible thinking. As research conducted by Adi (1977), analyzing reversible thinking of students through a problem of equations. The research conducted by Ramful and Olive (2008) also focused on the analysis of reversibility of thought. Ramful (2014) dan armful (2015) focused on research on reversible reasoning. The research by Simon, Kara, Placa, \& Sandir (2016) was producing categorizing and promoting reversibility of mathematical concepts.

These researches focused on analyzing students 'reversible thinking, not on learning strategies that could train students' reversible thinking. But that did not mean these studies were not important. These studies were very important because all of these results of researches were the basis of researchers to found approaches to solving reversible problems that could train students' reversible thinking. To find out the reversible thinking of students, most researchers previously used algebraic or arithmetic material. As exemplified by Adi (1978), that to reveal students' reversible thinking, Adi uses algebraic material. Namely students are asked to solve an equation $14-\frac{15}{7-x}=9$, through the process of student completion, it can be seen how students think reversibly. Whereas Wong (1977) uses arithmetic material, because according to Wong, thinking reversible is closely related to arithmetic, especially in addition operations. Maf'ulah, Juniati, and Siswono (2017) identified reversible thinking by giving algebraic problems in the form of a linear equation, then subject was asked to make other forms equivalent to the given equation.

But this study shows that thinking reversibly could also be investigated through functional object. As research conducted by Maf'ulah et al (2019), they investigated students' reversible thinking through functional object. And it did not rule out the possibility that to reveal reversible thinking, can use other object that is not functional, algebraic or arithmetic as suggested by Hackenberg \& Lee (2015), Ramful (2014), Simon et al., (2016), and Steffe \& Olive (2009) that reversibility can also be investigated on objects of function and inverse, derivatives and anti-derivatives, the rules of exponent and the rules of logarithm. That is, reversible thinking can be seen through a variety of mathematical object, but it needs to be considered the problem framework that will be given to students so they can explore students' reversible thinking skills.

The method was used the researchers to investigated reversible thinking of student is consistent with a study by Maf'ulah et. al (2019) who took high school students as their subject. They used 2 problems to identify students' reversible thinking. The first problem contained a function and the students were asked to delineate the graphic. The 
second problem contained a graphic and they were asked to define the function of the graphic. Those problems, therefore, were reversible.

Driscoll (1999) argued that reversible thinking did not involve a single process to reach an expected goal, but also another reversing process to the initial state in which the answer derived from. Hence, reversible thinking involved two processes; one process to reach the expected goal and another reversal one to go back to the initial state where everything came from. Relating to this study, a point in sector $z$ played a role as the initial state, and the point in sector $w$ was as the expected goal which constituted the result of transformation from sector $z$ through function $(\mathrm{z})$. The process of seeking for goals, therefore, was students' process to define the result of transformation in sector $w$ from one point in sector $z$ and an identified complex function $\mathrm{f}(\mathrm{z})$. In addition, the reversal process from the expected goal to the initial state referred to a process by students to define the point in sector $z$ from the result of transformation and the identified complex function.

The researchers, however, found neither published study nor article about learning strategy that might drill students' reversible thinking, in particular to prospective teachers. Therefore, this study might be used as a foothold to implement a learning strategy that improved students' reversible thinking, especially in math. Since reversible thinking ability is very important for students in solving problems (Krutetskii, 1976; Adi, 1978; Lamon 2007, Ramful \& Olive 2008; Fanders 2014; Maf'ulah, et. al., 2016; Maf'ulah, et. al., 2017; Maf'ulah, et. al., 2019).

The last discussion was about the causes of the low post test results. if seen from the mean of the control group's post-test which were quite low compared to the experimental group's, this could be due to the material discussed was about function in complex numbers which students had never previously studied before so that for the students in the control group was rather than difficult in answering questions because in learning not specifically trained or accustomed to the dealing with reversible problems.

The limitation of this study was reversible problem-solving approach was only tested on small samples. The researcher's suggestion for the next research is that this learning approach can be implemented on a larger sample.

\section{CONCLUSION}

The study was able to establish that a significant difference occurred between the experimental and control groups. Thus, the reversible-problem-solving approach in a learning process could affect the reversible thinking of prospective-math-teacher students. Therefore, providing reversible problems were likely to drill students' reversible thinking. That was, to train students' reversible thinking skills, researchers suggested to implement the reversible-problems-solving approach. The specific implications of the study to research and practice were (1) the results of this study can be used as inspiration for education observers, especially those relating to reversible thinking to carry out further research and (2) the reversible-problem-solving approach can be used as one of alternative to explore students' reversible thinking skills in learning mathematics which will later have a positive impact on problem solving skills. 


\section{ACKNOWLEDGEMENTS}

This article is one of the research results (Post-graduate or Pascadoctor research schame) funded by DRPM KEMENRISTEKDIKTI. The researchers thank the DRPM for funding this research so that this article can be published in internationally reputable journal. And also thank to the Leader or Rector of STKIP PGRI Jombang who had given permission to carry out Pascadoctor Research.

\section{REFERENCES}

Adi, H. (1978). Intellectual development and reversibility of thought in equation solving. Journal for Research in Mathematics Education, 9(3), 204-213.

Branca, N. A. (1980). Problem solving as a goal, process, and basic skill. In S. Krulik, \& R. E. Reyes (Eds.), Problem solving in school mathematics: 1980 yearbook (pp.3-8). Reston, VA: NCTM.

Dreyfus, T., \& Eisenberg, T. (1996). On different facets of mathematical thinking. In R. J. Sternberg, \& T. Ben-Zeev (Eds.), The nature of mathematical thinking (pp.253-284). Mahwah, NJ: Lawrence Erlbaum Associates.

Driscoll, M. (1999). Fostering algebraic thinking: A guide for teachers, grades 6-10. Portsmouth, NH: Heinemann.

Flanders, S. T. (2014) Investigating flexibility, reversibility, and multiple representations in a calculus environment (Unpub. Doct. dissertation) U. of Pittsburgh.

Heckenberg, A. J. (2010). Students' reasoning with reversible multiplicative relationships. Cognition and Instruction, 28(4), 383-432.

Hackenberg, A. J., \& Lee, M. Y. (2015). Relationships between students' fractional knowledge and equation writing. J. for Res in Mathematics Education, 46(2), 196-243.

Inhelder, B., \& Piaget, J. (1958). The growth of logical thinking from childhood to adolescence. New York: Basic Books.

Kothari, C. R. (2004). Research methodology (methods \& techniques). New Delhi: New Age Internasional (P) Limited Publisher.

Krutetskii, V. A. (1976). The psychology of mathematical abilities in schoolchildren. Chicago: The University of Chicago Press.

Lamon, S. (2007). Rational numbers and proportional reasoning: Towards a theoretical framework for research. In F. K. Lester (Ed.), Second handbook of research on mathematics teaching and learning (pp629-668). Charlotte, NC: Information Age.

Maf'ulah, S., Fitriyani, H., Yudianto, E., Fiantika, F. R., \& Hariastuti, R. M., (2019). Identifying the reversible thinking skill of students in solving function problems. Journal of Physics: Conference Series, 1188, 1-8. 
Maf'ulah S., Juniati, D., \& Siswono, T. Y. E., (2017). The aspects of reversible thinking in solving algebraic problems by an elementary student winning national olympiad medals in science. World Transactions on Engin. and Tech. Edu, 2(15), 189-194.

Maf'ulah S., Juniati, D., \& Siswono, T. Y. E., (2016). Pupils' error on the concept of reversibility in solving arithmetic problems. Edu. Res. and Rev, 11(18), 1775-1784.

NCTM. (2000). Principles and standards for school mathematics. Reston, VA: NCTM.

Piaget, J. (1985). The equilibration of cognitive structures (T. Brown, \& K. J. Thampy, Trans.). Chicago: The University of Chicago Press.

Polya, G. (1973). How to solve it. Princeton, NJ: Princeton University Press.

Ramful, A. (2015). Reversible reasoning and the working backwards problem solving strategy. Australian Mathematics Teacher,71(4), 28-32.

Ramful, A. (2009). Reversible reasoning in multiplicative situations: Conceptual analysis, affordances and constraints (Unpub. Doct. dissertation). U. of Georgia.

Ramful, A., \& Olive, J. (2008). Reversibility of thought: An instance in multiplicative tasks. The Journal of Mathematical Behavior, 27, 138-151.

Shumway, R. J. (1980). Research in mathematics education. Reston, VA: NCTM.

Simon, M. A., Kara, M., Placa, N., \& Sandir, H. (2016). Categorizing and promoting reversibility of mathematical concepts. Edu. Studies in Mathematics, 93(2), 137-153.

Slavin, R. E. (2006). Educational psychology: Theory and practice. Boston: Allyn \& Bacon.

Soedjadi, R. (1992). Orientasi kepada Kemampuan yang Transferable. Media Pendidikan Matematika Nasional Nomor 2. IKIP Surabaya.

Spiegel, M. R., Lipschutz, S., Schiller, J. J., \& Spellman, D. (2009). Complex variables. New York: McGraw-Hill.

Steffe, L. P., \& Olive, J. (2009). Children's fractional knowledge. Springer Science \& Business Media.

Sugiyono, (2015). Metode penelitian kombinasi (Mix Methods). Bandung: Alfabeta.

Wong, B. (1977). The relationship between Piaget's concept of reversibility and arithmetic performance among second graders. Paper presented at the Annual Meeting of the American Educational Research Association, New York, USA. 